\title{
Identifikasi Morfologi Rhizopus pada Oncom Hitam dari Berbagai Daerah di Indonesia
}

\section{Morphology Identification of Rhizopus in Black Oncom from Various Areas in Indonesia}

\section{Hartanti AT, Honggopertiwi A, Gunawan AW}

Fakultas Teknobiologi, Universitas Katolik Indonesia Atma Jaya, Jalan Cisauk, BSD City, Tangerang, Banten, 15345

Hartanti AT, Hanggopertiwi A, Gunawan AW. 2019- Identifikasi Rhizopus pada Oncom Hitam dari Berbagai Daerah di Indonesia. Jurnal Mikologi Indonesia 3 (2): 75-83.

\begin{abstract}
Abstrak
Oncom hitam merupakan produk fermentasi asli Indonesia yang dibuat dari bungkil kacang tanah sebagai substrat dan kapang Rhizopus spp. Sebagai agen fermentasi. Rhizopus yang berperan pada proses pembuatan oncom hitam perlu diketahui identitasnya serta dikonservasi sehingga dapat berguna untuk pengembangan fermentasi makanan yang aman untuk dikonsumsi. Penelitian ini bertujuan mengisolasi dan mengidentifikasi Rhizopus pada oncom hitam. Sampel diambil dari beberapa pasar tradisional di DKI Jakarta, Jawa Barat, dan Jawa Timur. Identifikasi Rhizopus dilakukan dengan pendekatan morfologi bentuk spora, kolumela, dan rizoid serta panjang sporangiofor, dan dengan pendekatan fisiologi pada suhu pertumbuhan $33,42,46,48$, dan $5^{\circ} \mathrm{C}$ pada medium agar-agar dekstrosa kentang. Identifikasi dilakukan mengikuti "A Monograph of Rhizopus". Rhizopus yang berhasil diisolasi dari sampel oncom hitam ialah sebanyak 13 galur yang terdiri atas $R$. arrhizus var. delemar $(R$. delemar), $R$. arrhizus var. tonkinensis ( $R$. oryzae), dan $R$. microsporus var. chinensis. Ketiganya merupakan varietas Rhizopus yang pertama kali dilaporkan ada pada oncom hitam.
\end{abstract}

Kata kunci - morfologi - suhu pertumbuhan maksimum - Rhizopus arrhizus var. delemar $R$. arrhizus var. tonkinensis-R. microsporus var. chinensis

\begin{abstract}
Oncom hitam is an authentic Indonesian fermented product made from peanut meal as a substrate and Rhizopus spp. as a fermentation agent. Rhizopus, which plays a role in the process of making black oncom, needs to be identified and conserved for further development of fermented foods that are safe for consumption. This study was aimed to isolate and identify Rhizopus on black oncom. Samples were taken from several traditional markets in DKI Jakarta, West Java, and East Java. Identification of Rhizopus was carried out based on a morphological examination such as spores, columella and rhizoid, and sporangiophore length; in combination with a physiological approach at different growth temperatures (33, $42,46,48$, and $51^{\circ} \mathrm{C}$ ) on potato dextrose agar medium. Identification was carried out following the "A Monograph of Rhizopus". A total three species of Rhizopus was determined from black oncom, namely, $R$. arrhizus var. delemar ( $R$. delemar), $R$. arrhizus var. Tonkinensis ( $R$. oryzae), and R. microsporus var. chinensis. All of them arenew reports associated with black oncom in Indonesia.
\end{abstract}


Key words - growth maximum temperature- morphology- Rhizopus arrhizus var. delemar$R$. arrhizus var. tonkinensis- $R$. microsporus var. chinensis

\section{Pendahuluan}

Oncom merupakan salah satu makanan hasil fermentasi kapang asli Indonesia khas Jawa Barat. Oncom yang beredar di masyarakat ada dua jenis, yaitu oncom merah dan oncom hitam. Oncom merah dibuat dari ampas tahu dengan kapang Neurospora, sedangkan oncom hitam dibuat dari kacang tanah dengan kapang Rhizopus.

Kandungan gizi, kadar besi, dan protein pada oncom hitam lebih tinggi daripada oncom merah (Slamet \& Tarwotjo 1971). Saono et al. (1974) melaporkan kapang yang berperan pada oncom hitam asal Bogor, Jawa Barat ialah $R$. oryzae dan pada oncom hitam asal Sukabumi, Jawa Barat ialah R. oligosporus. Rhizopus memiliki banyak spesies dan varietas yang telah dipelajari melalui berbagai pendekatan. Berdasarkan morfologi dan fisiologinya terdapat tiga grup besar Rhizopus, yaitu grup $R$. microsporus, $R$. oryzae, dan $R$. stolonifer (Schipper \& Stalpers 1984). Abe et al. (2006) melaporkan Rhizopus berdasarkan pada sekuens rDNA. Zheng et al. (2007) menyusun monograf Rhizopus berdasarkan pada morfologi, fisiologi, sistem kawin, dan pendekatan molekul dan mengemukakan ada 10 spesies dan 9 varietas Rhizopus. Taksonomi Rhizopus berdasarkan pada filogeni molekul mereduksi jumlah spesies karena $R$. niveus sinonim dengan $R$. delemar serta $R$. sexualis dan $R$. americanus sinonim dengan $R$. stolonifer (Abe et al. 2010).

Perkembangan taksonomi dari Rhizopus cukup pesat. Oleh karena itu, Rhizopus pada oncom hitam perlu diisolasi dan identifikasi. Hasil dari penelitian ini diharapkan dapat membantu standardisasi mutu pangan dan hasil konservasi Rhizopus asal Indonesia dapat digunakan untuk mengembangkan produk fermentasi asli Indonesia. Penelitian ini bertujuan mengisolasi, mengidentifikasi, dan mempreservasi spesies Rhizopus dari oncom hitam asal berbagai daerah di Pulau Jawa, Indonesia.

\section{Metode Penelitian Isolasi Rhizopus}

Bahan yang diperlukan dalam penelitian ini ialah oncom hitam dari berbagai daerah di DKI Jakarta, Jawa Barat, dan Jawa Timur. Penelitian ini terdiri atas pengambilan sampel, isolasi dan pemurnian, uji suhu pertumbuhan maksimum, serta pengamatan morfologi. Sampel diambil dari beberapa pasar tradisional di beberapa daerah di Pulau Jawa, Indonesia. Sampel oncom hitam disimpan pada suhu $4{ }^{\circ} \mathrm{C}$, untuk mencegah pembusukan.

Isolasi Rhizopus menggunakan medium agar-agar dektrosa kentang (ADK) pada cawan yang mengandung kloramfenikol 100 ppm. Oncom hitam dibelah dengan tangan, hifa yang diduga Rhizopus diambil dengan jarum jara, diinokulasikan pada agar-agar cawan, dan diinkubasi pada suhu $30{ }^{\circ} \mathrm{C}$ dalam inkubator (Zheng et al. 2007). Koloni Rhizopus umur 3-4 hari diamati strukturnya menggunakan mikroskop. Koloni tersebut selanjutnya dimurnikan menggunakan medium agar-agar air 2\% (b/v). Biakan Rhizopus yang tumbuh diambil ujung hifanya dan diinokulasi pada medium ADK cawan, selanjutnya diinkubasi pada suhu $30{ }^{\circ} \mathrm{C}$ selama 1-2 hari. Biakan Rhizopus yang telah murni diremajakan pada 5 medium ADK miring dan diinkubasi selama 2-3 hari: 1 tabung sebagai biakan kerja dan 4 tabung sebagai biakan koleksi di simpan di dalam kulkas suhu $4{ }^{\circ} \mathrm{C}$.

\section{Uji Pertumbuhan Maksimum Rhizopus}

Uji suhu pertumbuhan maksimum semua galur Rhizopus dilakukan pada cawan ADK dengan diameter $9 \mathrm{~cm}$. Koloni galur Rhizopus berumur 3 hari, berdiameter $5 \mathrm{~mm}$ ditumbuhkan di bagian tengah cawan ADK, lalu diinkubasi pada beberapa suhu pertumbuhan: 33, 42, 46,48 , dan $51{ }^{\circ} \mathrm{C}$. Setiap perlakuan diulang dua kali. 


\section{Pengamatan Morfologi Rhizopus}

Pengamatan morfologi galur Rhizopus menggunakan preparat yang dibuat mengikuti metode Riddle (Riddle 1950). Setiap galur diamati bentuk dan ukuran spora, bentuk kolumela dan rizoid, serta panjang sporangiofor. Morfologi tersebut diamati menggunakan mikroskop yang dilengkapi alat Dino-Eye AM7025X untuk pengukurannya. Hasil pengamatan diidentifikasi mengikuti buku "A Monograph of Rhizopus" (Zheng et al. 2007).

\section{Preservasi Rhizopus}

Preservasi Rhizopus menggunakan medium trehalosa gliserol yaitu campuran $5 \mathrm{~g}$ trehalosa ditambahkan $10 \mathrm{~mL}$ gliserol selanjutnya ditambahkan akuades sampai volume total menjadi $100 \mathrm{~mL}$ diaduk supaya homogen. Sebanyak $3 \mathrm{~mL}$ medium trehalosa gliserol dituang kedalam vial berukuran $5 \mathrm{~mL}$ dan disterilisasi. Preservasi dilakukan dengan cara membuat biakan murni Rhizopus yang berumur 5 hari pada medium PDA agar cawan, kemudian dibuat cetakan menggunakan sedotan steril berdiameter $4 \mathrm{~mm}$, cetakan biakan selanjutnya dimasukkan dalam medium trehalosa gliserol sebanyak 5 cetakan pada masing masing vial. Vial yang telah diisi biakan selanjutnya disimpan di lemari pendingin bersuhu $4{ }^{\circ} \mathrm{C}$ selama 24 jam, dan selanjutnya diletakkan di freezer $-80^{\circ} \mathrm{C}$.

\section{Hasil}

Rhizopus dari sampel oncom hitam asal beberapa pasar tradisional di DKI Jakarta, Jawa Barat, dan Jawa Timur yang berhasil diisolasi dan dimurnikan sebanyak 13 galur. Ketiga belas galur tersebut memiliki suhu pertumbuhan bervariasi: Rhizopus galur AH5, $\mathrm{AH} 8$, dan $\mathrm{AH} 12$ dengan suhu maksimum $42^{\circ} \mathrm{C}$; Rhizopus galur $\mathrm{AH} 3$ dengan suhu maksimum $46{ }^{\circ} \mathrm{C}$; dan 9 galur Rhizopus lainnya (AH, AH1A, AH1B, AH4, AH6, AH10, AH16, AH17, dan AH18) dengan suhu maksimum $48{ }^{\circ} \mathrm{C}$ (Tabel 1).

Tabel 1 Suhu pertumbuhan maksimum galur Rhizopus dari oncom hitam asal beberapa pasar di Pulau Jawa

\begin{tabular}{lllc}
\hline No. & Kode Galur & Asal Oncom Hitam & $\begin{array}{c}\text { Suhu pertumbuhan } \\
\text { maksimum }\left({ }^{\circ} \mathrm{C}\right)\end{array}$ \\
\cline { 3 - 4 } & AH5 & Bogor, Jawa Barat & 42 \\
2 & AH8 & Bogor, Jawa Barat & 42 \\
3 & AH12 & Curug, Jawa Barat & 42 \\
4 & AH3 & Jakarta Barat, DKI Jakarta & 46 \\
5 & AH & Jakarta Pusat, DKI Jakarta & 48 \\
6 & AH1A & Bogor, Jawa Barat & 48 \\
7 & AH1B & Bogor, Jawa Barat & 48 \\
8 & AH4 & Bogor, Jawa Barat & 48 \\
9 & AH6 & Bogor, Jawa Barat & 48 \\
10 & AH10 & Padalarang, Jawa Barat & 48 \\
11 & AH16 & Malang, Jawa Timur & 48 \\
12 & AH17 & Malang, Jawa Timur & 48 \\
13 & AH18 & Malang, Jawa Timur & \\
\hline
\end{tabular}

Berdasarkan pada suhu maksimum pertumbuhan Rhizopus dan ciri-ciri morfologi Rhizopus mengikuti kunci identifikasi dalam buku "A Monograph of Rhizopus"maka galur AH5 dan AH8 diidentifikasi sebagai $R$. arrhizus var. delemar, galur AH12 sebagai $R$. arrhizus var. tonkinensis, dan galur AH, AH1A, AH1B, AH4, AH6, AH10, AH16, AH17, dan AH18 sebagai R. microsporus var. chinensis. 
Rhizopus arrhizus var. delemar (Wehmer \& Hanzawa) J. J. Ellis, Mycologia 77: 247. 1985. = Rhizopus delemar Wehmer \& Hanzawain Hanzawa, Mycol. Zentrbl. 1:86

= Mucor delemar Boidin. (nom.nud)

Warna koloni galur ini putih yang kemudian menjadi abu-abu dengan tinggi 3-5 mm pada medium ADK pada suhu $33{ }^{\circ} \mathrm{C}$ setelah 3 hari (Gambar 1a). Bentuk rizoid seperti jari, sederhana, dengan pertumbuhan kurang baik. Sporangiofor tumbuh berlawanan dengan rizoid (Gambar 1b) dengan panjang 225.2-980.4 $\mu \mathrm{m}$ (Tabel 2). Bentuk sporangium membulat (Gambar 1c). Bentuk kolumela membulat (Gambar 1d), bulat mengerucut (Gambar 1e) dan tampak adanya kerah (Gambar 1f) serta apofisis (Gambar 1g). Bentuk sporangiospora beragam (Gambar 1h) dan bergoresan (Gambar 1i) dengan panjang5.9-16.8 $\mu \mathrm{m}$ (Tabel 3). Kapang ini membentuk klamidospora (Gambar 1j). Suhu pertumbuhan maksimum ialah 42 C.

Bahan yang diperiksa: oncom hitam, A Honggopertiwi. Provinsi Jawa Barat: Bogor, 11 September 2017, AH5 dan 12 September 2017, AH8.

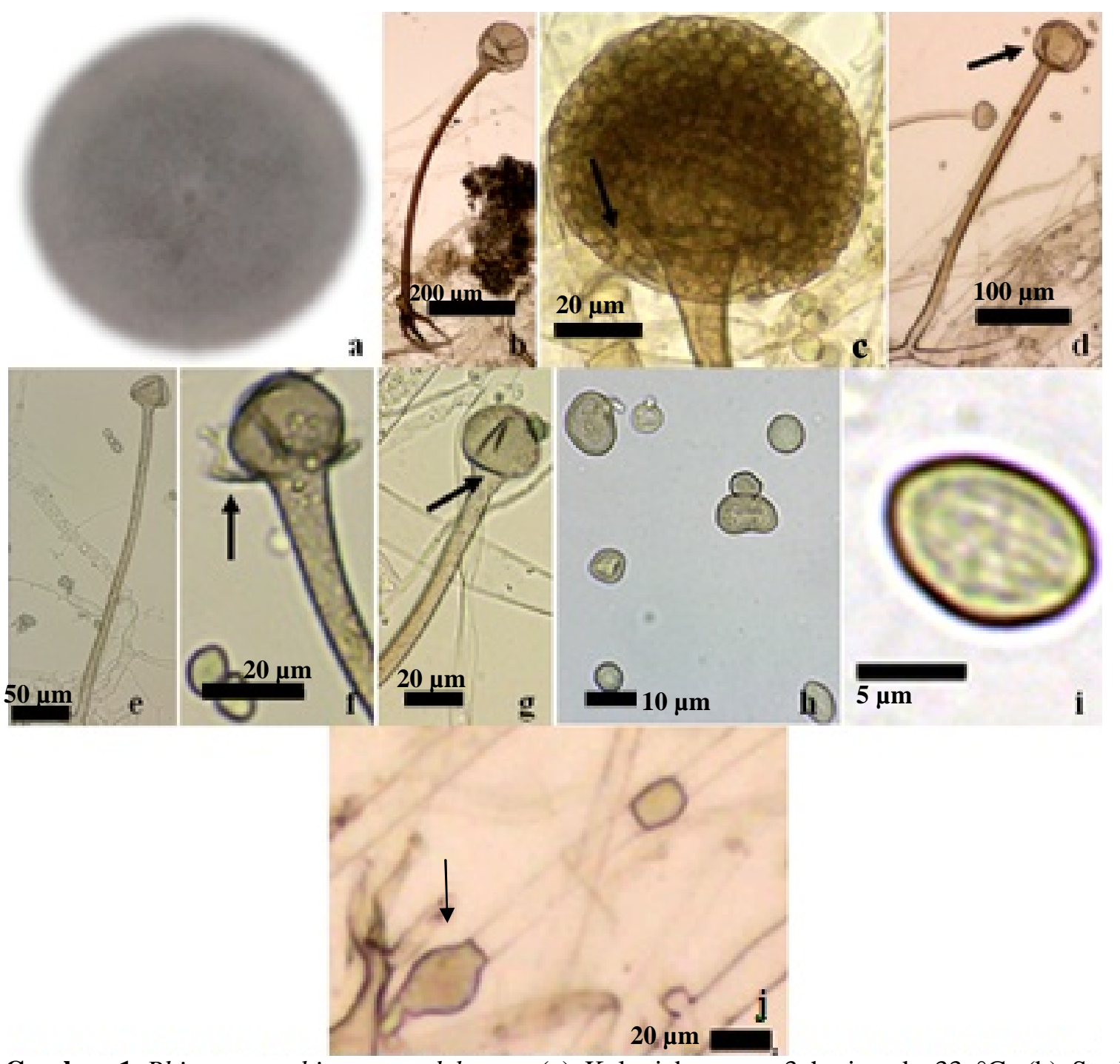

Gambar 1 Rhizopus arrhizus var. delemar: (a) Koloni berumur 3 hari pada $33{ }^{\circ} \mathrm{C}$, (b) Struktur reproduksi aseksual dan rizoid, (c) Sporangium agak bulat, (d) Sporangiofor tumbuh dari stolon dengan kolumela agak bulat (panah), (e) Kolumela bulat mengerucut, (f) Kerah (panah), (g) Apofisis (panah), (h) Sporangiospora beragam, (i) Sporangiospora bergoresan, dan (j) Klamidospora (panah). 
Rhizopus arrhizus var. tonkinensis (Vuill.) R. Y. Zheng \& X. Y. Liu.stat \& Comb.nov. $=$ Rhizopus tonkinensis Vuill.Rev. Mycol 24:53.1902 (Basionim)

$=$ Rhizopus boreas Yosh. Yamam. J.Soc.Agric.Forest.Sappero 17:493.1925

Warna koloni galur ini putih yang kemudian menjadi abu-abu dengan tinggi 3-5 mm pada medium ADK setelah 3 hari pada suhu $33{ }^{\circ} \mathrm{C}$ (Gambar 2a). Bentuk rizoidnya seperti jari dan sederhana serta bercabang (Gambar 2b). Sporangiofor tumbuh berlawanan dengan rizoid dan terkadang bercabang (Gambar 2c) dengan panjang 250.0-1271.0 $\mu \mathrm{m}$ (Tabel 2). Bentuk sporangium membulat (Gambar 2d). Bentuk kolumela bulat mengerucut (Gambar 2e). Bentuk sporangiospora seragam (Gambar 2f) dan bergoresan (Gambar 2g) dengan panjang antara 5.5-8.2 $\mu \mathrm{m}$ (Tabel 3), serta dijumpai ada klamidospora (Gambar 2h). Suhu partumbuhan maksimum ialah $42{ }^{\circ} \mathrm{C}$.

Bahan yang diperiksa: oncom hitam, A Honggopertiwi. Provinsi Jawa Barat, Curug, 14 September 2017, AH12.

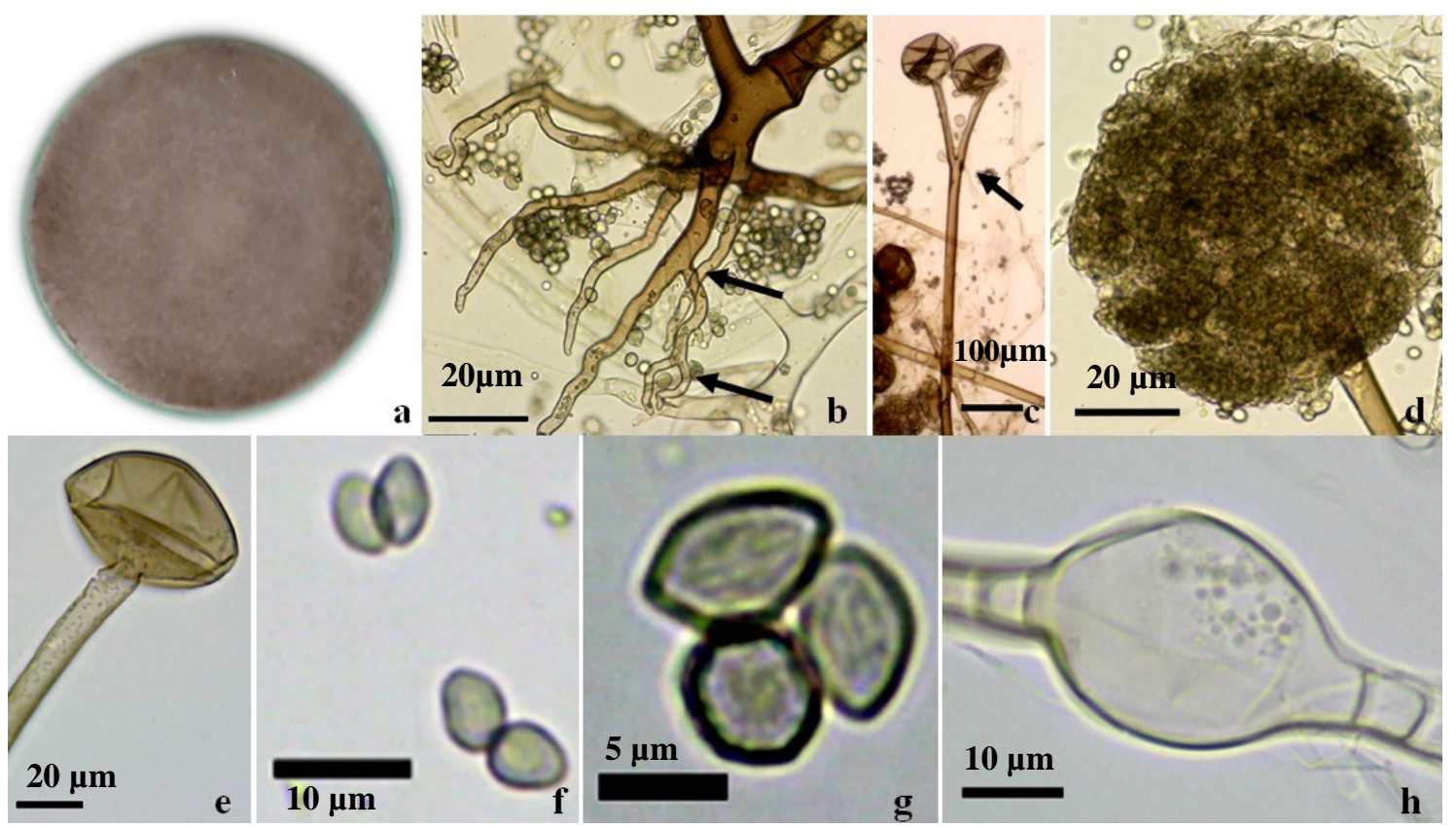

Gambar 2 Rhizopus arrhizus var. tonkinensis: (a) Koloni berumur 3 hari pada $33{ }^{\circ} \mathrm{C}$, (b) Rizoid bercabang (panah), (c) Sporangiofor bercabang (panah), (d) Sporangium membulat, (e) Kolumela bulat mengerucut, (f) Sporangiospora seragam, (g) Sporangiospor a bergoresan, dan (h) Klamidospora.

Rhizopus microsporus var. chinensis (Saito). Schipper-Stalpers. Stud. Mycol 25:31.1984. $=$ Rhizopus chinensis Saito. Zentbl. Bakt. ParasitKde, Abt.2,13:156.1904. $=$ Rhizopus bovines F.J.II.Beyma, Verh.K.Ned.Akad.Wet.,Scr. C, 29:38.1931

Warna koloni galur kapang ini putih yang kemudian menjadi abu-abu dan tinggi 3-5 mm pada medium ADK berumur 3 hari pada suhu $33{ }^{\circ} \mathrm{C}$ (Gambar $\left.3 \mathrm{a}\right)$. Bentuk rizoid seperti jari dan sederhana (Gambar 3b). Sporangiofor tumbuh berlawanan dengan rizoid dengan panjang 123.8-951.5 $\mu \mathrm{m}$ (Tabel 2). Bentuk kolumela beragam, yaitu membulat dengan kerah (Gambar 3c), membulat dan tampak adanya apofisis (Gambar 3d), bulat mengerucut (Gambar 3e), atau bulat telur melonjong (Gambar 3f). Bentuk sporangiospora seragam dan tidak bergoresan (Gambar 3g) dengan panjang 4.5-7 $\mu \mathrm{m}$ (Tabel 3), serta terdapat klamidospora 
(Gambar 3h). Suhu pertumbuhan maksimum galur AH3 ialah $46{ }^{\circ} \mathrm{C}$ dan 9 galur lainnya ialah $48^{\circ} \mathrm{C}$.

Sampel yang diperiksa: oncom hitam, A Honggopertiwi. Provinsi DKI Jakarta: Jakarta Pusat, 21 Agustus 2017, AH; Jakarta Barat, 7 September 2017, AH3. Provinsi Jawa Barat: Bogor, 21 November 2017, AH1A, 21 November 2017, AH1B, 11 September 2017, AH4, dan 11 September 2017, AH6; Padalarang, 14 September 2017, AH10. Provinsi Jawa Timur: Malang, 25 Desember 2017, AH16, 25 Desember 2017, AH17, dan 25 Desember 2017, AH18.

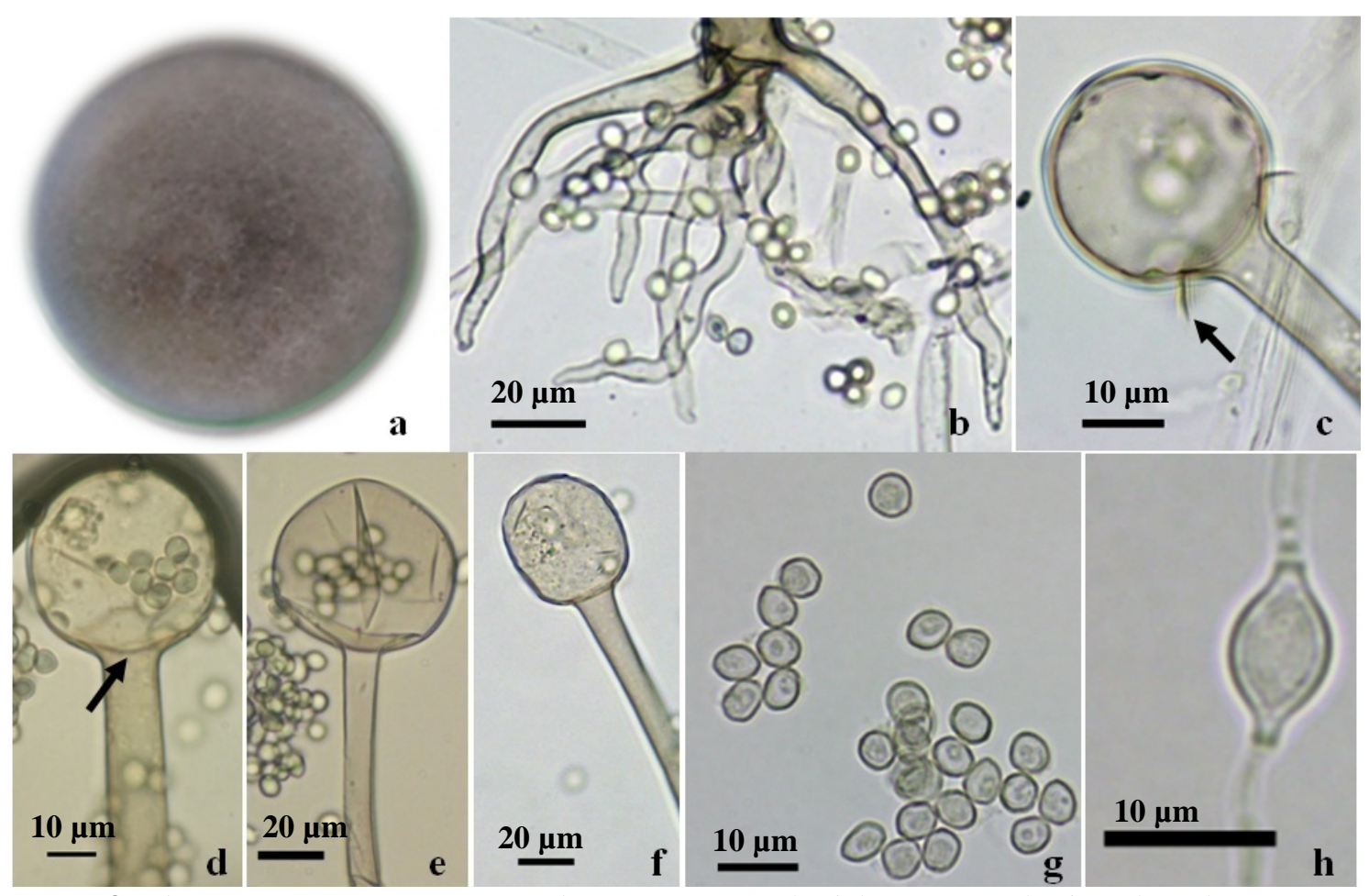

Gambar 3 Rhizopus microsporus var. chinensis: (a) Koloni berumur 3 hari pada suhu $33{ }^{\circ} \mathrm{C}$, (b) Rizoid, (c) Kolumela membulat dengan kolar (panah), (d) Kolumela agak bulat dengan apofisis (panah), (e) Kolumela bulat mengerucut, (f) Kolumela bulat telur melonjong, (g) Sporangiospora seragam bentuknya, (h) Klamidospora.

\section{Pembahasan}

Oncom berbahan dasar kacang tanah yang diperiksa berwarna abu-abu kehitaman dan terkadang abu-abu putih karena dipengaruhi oleh kapang yang tumbuh. Dalam penelitian ini Rhizopus pada oncom hitam diidentifikasi sebagai $R$. arrhizus var. delemar, $R$. arrhizus var. tonkinensis, dan $R$. microsporus var. chinensis. Saono et al.(1974) melaporkan $R$. oryzae terdapat pada oncom hitam asal Sukabumi, Jawa Barat, dan $R$. oligosporus pada oncom hitam asal Bogor, Jawa Barat.

Perlakuan suhu sangat penting dalam mengidentifikasi Rhizopus secara morfologi. Mengacu pada Zheng et al.(2007), Rhizopus dapat dikelompokkan menjadi 3 kelompok berdasarkan suhu pertumbuhan maksimum. Kelompok pertama yaitu Rhizopus yang memiliki suhu maksimum pertumbuhan $33{ }^{\circ} \mathrm{C}$ yaitu $R$. americanus, $R$ sexualis, $R$ stolonifer dan $R$. reflexus. Kelompok 2 yaitu Rhizopus yang memiliki pertumbuhan maksimum $42^{\circ} \mathrm{C}$, meliputi $R$. arrhizus var. arrhizus, var. delemar dan var. tonkinensis. Kelompok ketiga yaitu Rhizopus yang memiliki pertumbuhan maksimum $51{ }^{\circ} \mathrm{C}$, ialah $R$. niveus, $R$. homotallicus, $R$. microsporus, $R$. caespitosus dan $R$. schipperae. Oleh karena itu, perlakuan suhu penting dilakukan di awal identifikasi secara morfologi. 
Rhizopus arrhizus var. delemar yang ditemukan pada oncom hitam asal Bogor, Jawa Barat ada dua galur. Zheng et al. (2007) menggunakan biakan koleksi Rhizopus galur CBS 385.34 yang diisolasi dari tempe Indonesia dan Rhizopus galur CBS 402.51 dari ragi Jepang. Keduanya diidentifikasi sebagai $R$. arrhizus var. delemar. Abe et al. (2007) menggunakan biakan yang sama dengan yang digunakan oleh Zheng et al. (2007) mengidentifikasi dengan pendekatan molekul rDNA-ITS, $l d h \mathrm{~B}$, EF-1 $\alpha$, dan act 1 , dan menentukannya sebagai $R$. delemar karena menghasilkan asam malat-fumarat. Asam yang dihasilkan ini membuat oncom hitam memiliki rasa asam dan aroma yang khas. Oleh karena itu, $R$. arrhizus var. delemar merupakan sinonim dari $R$. delemar. Hartanti et al. (2015) melaporkan keberadaan $R$. delemar pada tempe Indonesia hanya terdapat di Palu, Sulawesi Tengah. Kapang $R$. delemar telah banyak dikonsumsi oleh orang Asia sebagai makanan fermentasi dan tidak ada efek samping pada hewan dan tanaman (Saito et al. 2004).

Tabel 2 Morfologi galur Rhizopus dari oncom hitam

\begin{tabular}{|c|c|c|c|c|c|c|}
\hline \multirow{2}{*}{ No } & \multirow{2}{*}{$\begin{array}{l}\text { Kode } \\
\text { Galur }\end{array}$} & \multirow{2}{*}{ Bentuk Rizoid } & \multicolumn{2}{|c|}{ Sporangiospora } & \multirow{2}{*}{$\begin{array}{c}\text { Panjang } \\
\text { Sporangiofor }(\mu \mathrm{m})\end{array}$} & \multirow{2}{*}{ Bentuk Kolumela } \\
\hline & & & Bentuk & Panjang $(\mu \mathrm{m})$ & & \\
\hline 1 & AH5 & Seperti jari, sederhana & beragam & $6.1-14.0$ & $184.8-615.5$ & agak bulat \\
\hline 2 & AH8 & Seperti jari, sederhana & beragam & $5.9-16.8$ & 225.2-980.4 & agak bulat \\
\hline 3 & AH12 & Seperti jari, sederhana & seragam & $5.5-8.2$ & $250.0-1271.0$ & bulat mengerucut \\
\hline 4 & $\mathrm{AH} 3$ & Seperti jari, sederhana & seragam & $4.8-6.1$ & $225.6-714.0$ & $\begin{array}{l}\text { membulat, agak bulat, } \\
\text { bulat telur melonjong }\end{array}$ \\
\hline 5 & $\mathrm{AH}$ & seperti jari, sederhana & seragam & $4.5-6.0$ & 215.5-688.0 & $\begin{array}{l}\text { membulat, agak bulat, } \\
\text { bulat telur melonjong }\end{array}$ \\
\hline 6 & AH1A & seperti jari, sederhana & seragam & $5.3-6.8$ & $204.0-745.5$ & $\begin{array}{l}\text { membulat, agak bulat, } \\
\text { bulat telur melonjong }\end{array}$ \\
\hline 7 & AH1B & seperti jari, sederhana & seragam & $5.3-6.1$ & $130.4-534.8$ & $\begin{array}{l}\text { membulat, agak bulat, } \\
\text { bulat telur melonjong }\end{array}$ \\
\hline 8 & $\mathrm{AH} 4$ & seperti jari, sederhana & seragam & $4.5-6.0$ & $134.4-841.2$ & $\begin{array}{l}\text { membulat, agak bulat, } \\
\text { bulat telur melonjong }\end{array}$ \\
\hline 9 & AH6 & seperti jari, sederhana & seragam & $4.6-7.1$ & $255.0-951.5$ & $\begin{array}{l}\text { membulat, agak bulat, } \\
\text { bulat telurmelonjong }\end{array}$ \\
\hline 10 & AH10 & seperti jari, sederhana & seragam & $5.1-7.0$ & $125.4-485.0$ & $\begin{array}{l}\text { membulat, agak bulat, } \\
\text { bulat telurmelonjong }\end{array}$ \\
\hline 11 & AH16 & seperti jari, sederhana & seragam & $4.6-6.3$ & $123.8-981.2$ & $\begin{array}{l}\text { membulat, agak bulat, } \\
\text { bulat telurmelonjong }\end{array}$ \\
\hline 12 & AH17 & seperti jari, sederhana & seragam & $4.5-6.2$ & $173.7-666.6$ & $\begin{array}{l}\text { membulat, agak bulat, } \\
\text { bulat telurmelonjong }\end{array}$ \\
\hline 13 & AH18 & seperti jari, sederhana & seragam & $4.5-6.6$ & $166.0-355.0$ & $\begin{array}{l}\text { membulat, agak bulat, } \\
\text { bulat telurmelonjong }\end{array}$ \\
\hline
\end{tabular}

Satu biakan yang diisolasi dari oncom hitam asal Curug, Jawa Barat merupakan $R$. arrhizus var. tonkinensis. Galur CBS 257.28 yang diisolasi dari Formosan China dan galur CBS 330.53 dari tanah Jepang dilaporkan sebagai $R$. arrhizus var. tonkinensis (Zheng et al. 2007). Abe et al. (2007) menggunakan biakan yang sama, yaitugalur CBS 257.28 dan galur CBS 330.53, dan mengidentifikasinya sebagai $R$. oryzae karena kedua galur tersebut menghasilkan asam laktat. Jadi, $R$. arrhizus var. tonkinensis merupakan sinonim dari $R$. oryzae.

Galur-galur yang ditemukan pada penelitian ini pernah ditemukan pada makanan fermentasi di Indonesia pada kurun waktu yang sudah cukup lama. Hal ini penting diteliti kembali, karena adanya komersialisasi ragi yang mendominasi dalam pembuatan tempe, sehingga perlu dikaji kembali biodiversitas Rhizopus yang digunakan dalam fermentasi makanan di Indonesia, dan dipreservasi. Galur-galur tersebut dapat digunakan sebagai alternatif untuk pengembangan makanan fermentasi Indonesia, dan jangan sampai punah karena adanya ragi komersial. Galur-galur tersebut juga pernah ditemukan di substrat lain 
selain di bungkil kacang, yaitu di substrat tanah, daun yang telah gugur, di urin dari pasien yang kena mucormikosis, ataupun di udara (Zheng et al. 2007), namun belum ada yang melaporkan ada pada oncom hitam.

Rhizopus delemar dan $R$. oryzae dinyatakan sebagai satu grup yang sama, yaitu $R$. oryzae oleh Schipper \& Stalpers (1984). Oda et al. (2002) mengelompokkan grup $R$. oryzae menjadi dua kelompok berdasarkan pada senyawa metabolit yang dihasilkan, yaitu asam laktat dan asam fumarat. Abe et al. (2003) menggunakan 69 biakan $R$. oryzae dengan pendekatan molekul rDNA ITS dan menyatakan terdapat dua kelompok $R$. oryzae, yaitu $R$. oryzae penghasil asam laktat dan $R$. oryzae penghasil asam malat-fumarat. Pada tahun 2007 Abe et al. mengusulkan $R$. oryzae yang menghasilkan asam malat-fumarat sebagai $R$. delemar, sesuai dengan nama pertama yang diberikan untuk galur penghasil asammalatfumarat, yaitu $R$. delemar (Boidin) Wehmer \& Hanzawa.

Selain ditinjau dari suhu pertumbuhan maksimum, $R$. delemar dan $R$. oryzae dapat dibedakan melalui pengamatan morfologi, $R$. delemar memiliki sporangiospora yang bervariasi dalam bentuk dan ukuran, serta memiliki pembengkakan pada sporangiofornya di bagian atas. Sedangkan $R$. oryzae memiliki sporangiospora yang seragam dalam bentuk dan ukurannya.

Sepuluh galur dari oncom hitam merupakan $R$. microsporus var. chinensis. Penyebaran spesies ini juga cukup luas di Pulau Jawa, mulai dari DKI Jakarta, Jawa Barat, dan Jawa Timur. Zheng et al. (2007) mengidentifikasi galur CBS 294.31 yang diisolasi dari janin sapi di Perancis dan galur CBS 631.82 dari koji Cina dan keduanya merupakan $R$. microsporus var. chinensis. Abe et al. (2010) dengan menggunakan pendekatan molekul dengan marka rDNA-ITS, act1, dan EF-1 $\alpha$, menyatakan bahwa $R$. microspores belum dapat dikelompokkan dalam intra spesies. $R$. microsporus var. chinensis dapat menghasilkan enzim $\alpha$-amilase, glukoamilase $\mathrm{A}$, dan glukoamilase B yang mampu memecah pati mentah (Li et al. 2010).

Dalam penelitian ini tidak diperoleh $R$. microsporus var. oligosporus yang selama ini lebih dikenal sebagai $R$. oligosporus pada tempe. Padahal Rhizopus tersebut sering terdapat pada tempe di berbagai daerah di Indonesia (Hartanti et al. 2015). Kemungkinan besar, inokulum yang dipakai sebagai starter dalam pembuatan oncom hitam tidak menggunakan laru tempe komersial yang banyak beredar di pasar, akan tetapi memakai laru turunan dari oncom hitam itu sendiri. Oncom dibuat tidak terlalu steril sehingga kemungkinan Rhizopus yang berperan dapat berasal dari lingkungan sekitarnya.

Pada penelitian ini belum dilakukan identifikasi secara molekuler, untuk itu selanjutnya perlu dilakukan identifikasi secara molekuler. Identifikasi berdasarkan morfologi dan suhu pertumbuhan ini masih dapat dikembangkan dengan menggunakan pendekatan lain, seperti pendekatan molekul dan identifikasi senyawa yang dihasilkan. Dolatabadi et al. (2014) menyatakan sering terjadi kegagalan dalam identifikasi varietas $R$. microspores dengan pendekatan molekul, seperti yang dilaporkan oleh Abe et al. (2006). Oleh karena itu, pendekatan morfologi, fisiologi, sistem kawin, MALDI-TOF, ITS, ACT, dan TEF, masih diperlukan.

Kapang oncom hitam berdasarkan pada pendekatan morfologi diidentifikasi sebagai $R$. arrhizus var. delemar ( $R$. delemar), $R$. arrhizus var. tonkinensis $(R$. oryzae) dan $R$. microsporus var. chinensis. Ketiganya merupakan varietas Rhizopus yang belum pernah dilaporkan ada pada oncom hitam.

\section{Ucapan Terima Kasih}

Penelitian ini didanai melalui Hibah FakultasTeknobiologi-Unika Atma Jaya atas nama Anastasia Tatik Hartanti dan Agustin Wydia Gunawan. 


\section{Pustaka}

Abe A, Sone T, Sujaya IN, Saito K, Oda Y, Asano K, Tomita F. 2003-rDNA ITS sequence of Rhizopus oryzae: its application to classification and identification of lactic acid producers. Biosci Biotechnol Biochem. 67(8), 1725-1731.

Abe A, Oda Y, Asano K, Sone T. 2006- The molecular phylogenic of the genus Rhizopus base on rDNA sequences. Biosci Biotechnol Biochem. 70(10),2387-2393. doi: 10.1271/bbb.60101

Abe A, Oda Y, Asano K, Sone T. 2007-Rhizopus delemar is the proper name for fumaric malic acid producers. Mycologia. 99, 714-722.

Abe A, Asano K, Sone T. 2010-A molecular phylogeny-based taxonomy of the genus Rhizopus. BiosciBiotechnolBiochem. 74(7), 1325-1331. doi.org/10.1 271/bbb.90718

Dolatabadi S, Walther G, Gerrits van den Ende AHG, de Hoog GS. 2014-Diversity and delimitation of Rhizopus microsporus. Fungal Divers 64, 145-163. doi: 10.1007/s13225-013-0229-6

Hartanti AT, Rahayu G, Hidayat I. 2015-Rhizopus species from fresh tempeh collected from several regions in Indonesia. Hayati J Biosci. 22, 136-142.

Li YN, Shi GY, Wang W, Wang ZX. 2010-A newly isolated Rhizopus micropsorus var. chinensis capable of secreting amylolytic enzymes with raw-starch-degesting activity. Microbiol Biotechnol. 20(2),383-390. doi: 10.4014/jmb.0 907.07025

Oda Y, Saito K, Yamauchi H, Mori M. 2002-Lactic acid fermentation of potato pulp by the fungus Rhizopus oryzae. Curr Microbiol. 45, 1-4. doi: 10.1007/s00284-001-0048-y

Riddle RW. 1950-Permanent strained mycological preparation obtained by slide culture. Mycologia.42, 265-270.

Saito K. Abe A, Sujaya IN, Sone T, Oda Y. 2004-Comparison of Amylomyces rouxii and Rhizopus oryzae in lactic acid fermentation of potato pulp. Food Sci Technol Res. 10 (2), 224-226.

Saono S, Gandjar I, Basuki T, Karsono H. 1974-Mycoflora of "ragi" and some other traditional fermented foods of Indonesia. Ann Bogor. 5 (4),187-196.

Schipper MAA, Stalpers JA. 1984-A revision of the genus Rhizopus. 2. the Rhizopus microsporus group. Stud Mycol. 25, 20-34.

Slamet DS, Tarwotjo I. 1971-Kadar zat gizi dalam ontjom. Nutr Food Res.1, 49-52.

Zheng RY, Chen GQ, Huang H, Liu XY. 2007-A monograph of Rhizopus. Sydowia. 59 (2), 273-372. 